\title{
Expression and function of $\alpha \beta 1$ integrins in pancretic beta (INS-1) cells
}

\author{
Mansa Krishnamurthy $•$ Jinming Li • \\ Maia Al-Masri $\cdot$ Rennian Wang
}

Received: 22 August 2008 / Accepted: 16 October 2008 /Published online: 21 November 2008

(C) The Author(s) 2008. This article is published with open access at Springerlink.com

\begin{abstract}
Integrin-extracellular matrix interactions are important determinants of beta cell behaviours. The $\beta 1$ integrin is a well-known regulator of beta cell activities; however, little is known of its associated $\alpha$ subunits. In the present study, $\alpha \beta 1$ integrin expression was examined in the rat insulinoma cell line (INS-1) to identify their role in beta cell survival and function. Seven $\alpha$ subunits associated with $\beta 1$ integrin were identified, including $\alpha 1-6$ and $\alpha \mathrm{V}$. Among these heterodimers, $\alpha 3 \beta 1$ was most highly expressed. Common ligands for the $\alpha 3 \beta 1$ integrin, including fibronectin, laminin, collagen I and collagen IV were tested to identify the most suitable matrix for INS-1 cell proliferation and function. Cells exposed to collagen I and IV demonstrated significant increases in adhesion, spreading, cell viability, proliferation, and FAK phosphorylation when compared to cells cultured on fibronectin, laminin and controls. Integrin-dependent attachment also had a beneficial
\end{abstract}

M. Krishnamurthy $\cdot$ J. Li $\cdot$ M. Al-Masri $\cdot$ R. Wang

Children's Health Research Institute,

University of Western Ontario,

London, Ontario, Canada

M. Krishnamurthy

Departments of Pathology, University of Western Ontario,

London, Ontario, Canada

J. Li $\cdot$ M. Al-Masri $\cdot$ R. Wang

Physiology \& Pharmacology, University of Western Ontario,

London, Ontario, Canada

R. Wang

Department of Medicine, University of Western Ontario,

London, Ontario, Canada

R. Wang $(\bowtie)$

Victoria Research Laboratories,

Room A5-140, 800 Commissioners Road East,

London, Ontario N6C 2V5, Canada

e-mail: rwang@uwo.ca effect on beta cell function, increasing Pdx-1 and insulin gene and protein expression on collagens I and IV, in parallel with increased basal insulin release and enhanced insulin secretion upon high glucose challenge. Furthermore, functional blockade of $\alpha 3 \beta 1$ integrin decreased cell adhesion, spreading and viability on both collagens and reduced Pdx-1 and insulin expression, indicating that its interactions with collagen matrices are important for beta cell survival and function. These results demonstrate that specific $\alpha \beta 1$ integrin-ECM interactions are critical regulators of INS-1 beta cell survival and function and will be important in designing optimal conditions for cell-based therapies for diabetes treatment.

Keywords Extracellular matrix · Integrins .

INS-1 cell line $\cdot$ Pdx-1

\section{Introduction}

Pancreatic beta cells are essential for rapid and precisely controlled responses to changes in blood glucose levels. Disturbance of their function leads to diabetes mellitus, a disease characterized by hyperglycemia and several other complications. Given that diabetes affects millions of people worldwide, recent research efforts have focused on devising cell-based strategies to promote beta cell survival and function, for either organ regenerative purposes or islet transplantation.

One such research focus is the extracellular matrix (ECM) and their receptors, the integrins. In addition to controlling morphogenetic decisions during development, maintaining homeostasis and providing a physical basis for the spatial organization of cells (Thiery et al. 2003), integrin-ECM interactions influence a variety of cellular behaviours including growth, differentiation and function 
(Boudreau and Jones 1999; Bouvard et al. 2001; Brakebusch and Fassler 2005; Coppolino and Dedhar 1999; Danen and Sonnenberg 2003; French-Constant and Colognato 2004; Juliano et al. 2004). A family of glycoproteins, integrins are composed of individual $\alpha$ and $\beta$ subunits which noncovalently link to form distinct heterodimeric receptors (Berman et al. 2003; Boudreau and Jones 1999; Coppolino and Dedhar 1999; Danen and Sonnenberg 2003; Lee and Juliano 2004). Their unique bi-directional signaling properties enable them to integrate exterior and interior environments of a cell and, thus, they influence a plethora of cellular processes including changes in migration, differentiation, proliferation and gene expression (Berman et al. 2003; Boudreau and Jones 1999; Bouvard et al. 2001; Brakebusch and Fassler 2005; Coppolino and Dedhar 1999; Danen and Sonnenberg 2003; French-Constant and Colognato 2004; Juliano et al. 2004; Lee and Juliano 2004).

In the field of islet cell biology, several studies have demonstrated that integrin-ECM interactions are critical for survival, differentiation and function. In isolated canine islets, disruption of integrin-ECM relationships induced apoptosis and enhanced the trans-differentiation of islets to a ductal phenotype (Wang and Rosenberg 1999; Wang et al. 2001). However, culturing these islets on fibronectin and collagen I matrices restored islet survival (Wang and Rosenberg 1999). Embedding isolated human adult islets in type I collagen gels increased insulin secretory responses (Montesano et al. 1983), while culturing human beta cells on bovine corneal endothelial matrix increased basal and stimulated insulin secretion levels (Kantengwa et al. 1997). Similarly, the culturing of rat islets on laminin-5 also increased insulin secretory responses (Hammar et al. 2004), while human fetal beta cells demonstrated significant increases in insulin secretion upon glucose stimulation and a reciprocal decline in insulin content when exposed to vitronectin and collagen IV matrices (Kaido et al. 2006). Taken together, these studies emphasize the importance of specific integrin-ECM relationships in potentiating beta cell survival and function.

$\beta 1$ integrin and its associated $\alpha$ subunits constitute the largest integrin subfamily (Brakebusch and Fassler 2005). Particular importance has been placed on these integrins as they orchestrate the majority of changes in beta cell behaviours and heavily influence alterations in hormone expression and secretion (Bosco et al. 2000; Kaido et al. 2004; Kantengwa et al. 1997, Wang et al. 2005; Yashpal et al. 2005). We have previously demonstrated the spatial and temporal expression patterns of $\beta 1$ integrin and its associated $\alpha 3, \alpha 5$ and $\alpha 6$ subunits in the developing human fetal and pre- and post-natal rat pancreas (Wang et al. 2005; Yashpal et al. 2005). Furthermore, integrins $\alpha \mathrm{V} \beta 1$ and $\alpha 1 \beta 1$ have been shown to facilitate human fetal islet cell adhesion, motility and insulin secretion on vitronectin and collagen IV matrices, respectively (Cirulli et al. 2000; Kaido et al. 2004). Similarly, integrins $\alpha 3 \beta 1$ and $\alpha 6 \beta 1$ increase rat and human adult islet cell adhesion and spreading, respectively, augmenting cell survival and insulin secretion (Bosco et al. 2000; Kantengwa et al. 1997).

The above findings have characterized the role of integrin-ECM relationships in islet cells; however the consequences of these interactions in the beta cell remain largely unknown. Moreover, specialized interactions between integrin receptors and specific matrix proteins, which enhance the survival and function of beta cells, has not been thoroughly studied. The goal of the present study was to characterize the $\alpha \beta 1$ integrin expression pattern in INS-1 pancreatic beta cells, a highly differentiated rat insulinoma cell line, which has been described as physiologically similar to native beta cells (Asfari et al. 1992; Janjic and Wolheim 1992; Yang et al. 2004). Alterations in beta cell behaviours, including adhesion, spreading, viability, proliferation and function were also examined, following exposure to various matrix proteins. Through immunofluorescence, qRT-PCR and western blotting, we identified seven $\alpha$ subunits, $\alpha 1-6$ and $\alpha \mathrm{V}$, of which $\alpha 3, \alpha 4$ and $\alpha 6$ co-immunoprecipitated with the $\beta 1$ integrin. Among these heterodimers, $\alpha 3 \beta 1$ was most highly expressed. Therefore, common ligands for this integrin, including fibronectin, laminin and collagen I and IV, were all tested. Our results revealed that both collagen matrices increased integrin-dependent attachment and spreading, enhanced INS-1 cell viability and proliferation, and increased FAK phosphorylation and focal adhesion contact assembly, when compared to fibronectin, laminin and control conditions. Moreover, culturing INS-1 cells on these collagen matrices enhanced insulin expression and increased basal insulin release as well as insulin secretion following a high glucose challenge. These observations provide us with a better understanding of integrin-ECM relationships that can be manipulated for improving beta cell-based therapies for the treatment of diabetes.

\section{Materials and methods}

\section{Cell culture}

INS-1 (832/13) cells (a gift from Dr. Christopher Newgard, Duke University Medical Center, USA) were cultured to 90\% confluency, in RPMI-1640 with L-glutamine containing $10 \%$ fetal bovine serum (FBS, Invitrogen, Burlington, ON, Canada), $10 \mathrm{mmol} / 1$ HEPES (Sigma, St. Louis, MO, USA), $1 \mathrm{mmol} / \mathrm{L}$ sodium pyruvate (Invitrogen) and $50 \mu \mathrm{mol} / 1 \beta$-mercaptoethanol (Sigma) (Jensen et al. 2001; Pederson et al. 2007). 
Table 1 List of antibodies/ antisera used for immunofluorescence and western blotting

a dilution factor applied for the western blot

Adhesion/Spreading assay

$1 \times 10^{5}$ cells were plated on 96-well tissue culture plates (Fisher Scientific, Ottawa, ON, Canada) pre-coated with $5 \mu \mathrm{g} / \mathrm{ml}$ of either fibronectin, laminin (Chemicon, Temecula, CA, USA), rat tail collagen I, collagen IV (BD Biosciences, Mississauga, ON, Canada) or control (BSA, Sigma) in serum-free medium and cultured for $3 \mathrm{~h}$. Non-adhered cells were removed by washing wells twice with phosphate buffer saline [PBS]. Six random fields were imaged per well, at 40X magnification, using a Leica DMIRE2 fluorescence microscope with Openlab image software (Improvision, Lexington, MA, USA). Cells that attached and spread were counted and normalized to control groups, and the data expressed as fold changes. Each experiment was conducted in triplicate with at least six repeat experiments per group.

\section{MTT assay}

Cell viability was examined using an MTT assay (Li et al. 2006). $1 \times 10^{4}$ cells were plated per well in 96-well tissue culture plates (Fisher Scientific) pre-coated with $5 \mu \mathrm{g} / \mathrm{ml}$ of

Table 2 RT-PCR and qRT-PCR primer sequence information

\begin{tabular}{|c|c|c|c|}
\hline Primer & Primer pair sequence & Accession \# & Fragment size (bp) \\
\hline$\beta 1$ Integrin & $\begin{array}{l}\text { 5'-TGG TCA GCA GCG CAT ATC TGG A-3' } \\
5^{\prime} \text {-GCC CAC TGC TGA CTT AGG AAT-3' }\end{array}$ & NM_017022.1 & 367 \\
\hline$\alpha 1$ Integrin & $\begin{array}{l}\text { 5'-GGC CCT GGT CAC TAT TGT TA-3' } \\
5^{\prime} \text {-CAT GAC CAC AGT TCC GTT CC-3' }\end{array}$ & NM_030994.1 & 184 \\
\hline$\alpha 2$ Integrin & $\begin{array}{l}\text { 5'-AAG TAA CAT GCC AGA TTG GT-3' } \\
\text { 5'-CTA TGA GGC TGA CCG AAT TG-3' }\end{array}$ & XM_345156.3 & 204 \\
\hline$\alpha 3$ Integrin & $\begin{array}{l}\text { 5'-GAA CGA TTG TGA ACG CAT GG-3' } \\
\text { 5'-GCC AGG GTC GAG CTG TAG GT-3' }\end{array}$ & XM_340884.3 & 223 \\
\hline$\alpha 4$ Integrin & $\begin{array}{l}\text { 5'-CAG CAT TGA TGA AAG CGA AC-3' } \\
5^{\prime}-\text { GTC ACT TCC GAC GAG CAC TC-3' }\end{array}$ & XM_230033.4 & 235 \\
\hline$\alpha 5$ Integrin & $\begin{array}{l}\text { 5'-ACC AGA GCA AGA GCC GGA TA-3' } \\
5^{\prime} \text {-TGG TTC ACC GCG AAG TAG TCA-3' }\end{array}$ & XM_235707.4 & 289 \\
\hline$\alpha 6$ Integrin & $\begin{array}{l}\text { 5'-CGC GCA CAG AGG CCG TAG CA-3' } \\
\text { 5'-CAC GTT GTC CTC GCG GGT AT-3' }\end{array}$ & XM_215984.4 & 150 \\
\hline$\alpha \mathrm{V}$ Integrin & $\begin{array}{l}\text { 5'-TGA ACC TCC AGT GGC CTT AC-3' } \\
\text { 5'-GCG CTC TTC CCT CTA TCC AG-3' }\end{array}$ & XM_230950.4 & 286 \\
\hline Pdx-1 & $\begin{array}{l}\text { 5'-GGC TTA ACC TAA ACG CCA CA-3' } \\
\text { 5'-AGA GTC CCA GAG GCA GAC CT-3' }\end{array}$ & NM_022852.3 & 175 \\
\hline Insulin I & $\begin{array}{l}\text { 5'-CCC AAG TCC CGT CGT GAA GT-3' } \\
\text { 5'-TGA TCC ACA ATG CCA CGC TTC T-3' }\end{array}$ & NM_019129.1 & 128 \\
\hline Insulin II & 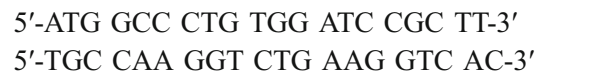 & NM_019130.1 & 243 \\
\hline $18 \mathrm{~S}$ & $\begin{array}{l}\text { 5'-GTA ACC CGT TGA ACC CCA TTC-3' } \\
5^{\prime} \text {-CCA TCC AAT CGG TAG TAG CG-3' }\end{array}$ & M11188.1 & 151 \\
\hline
\end{tabular}


A
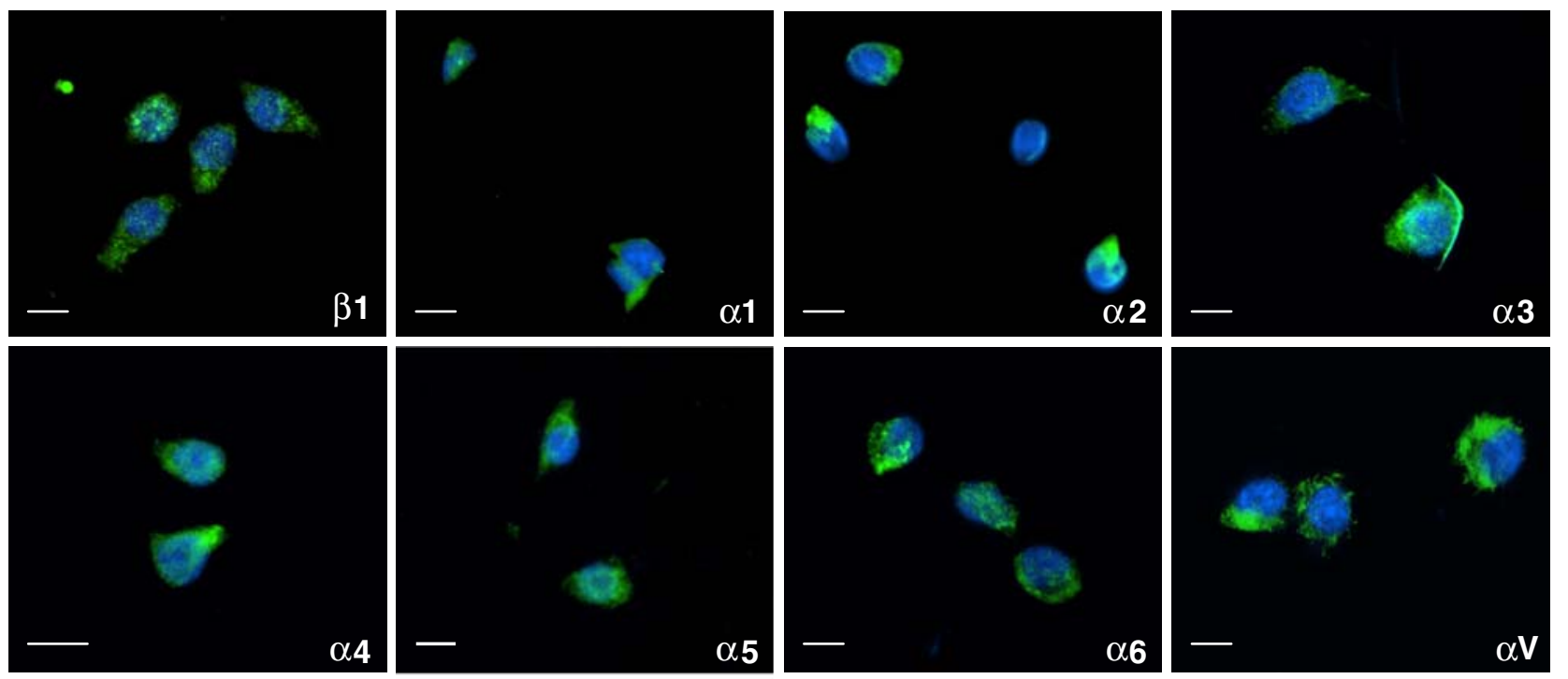

B

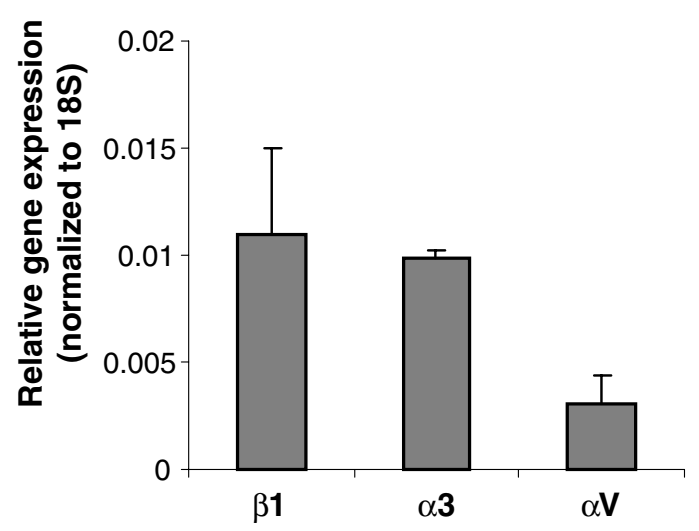

C
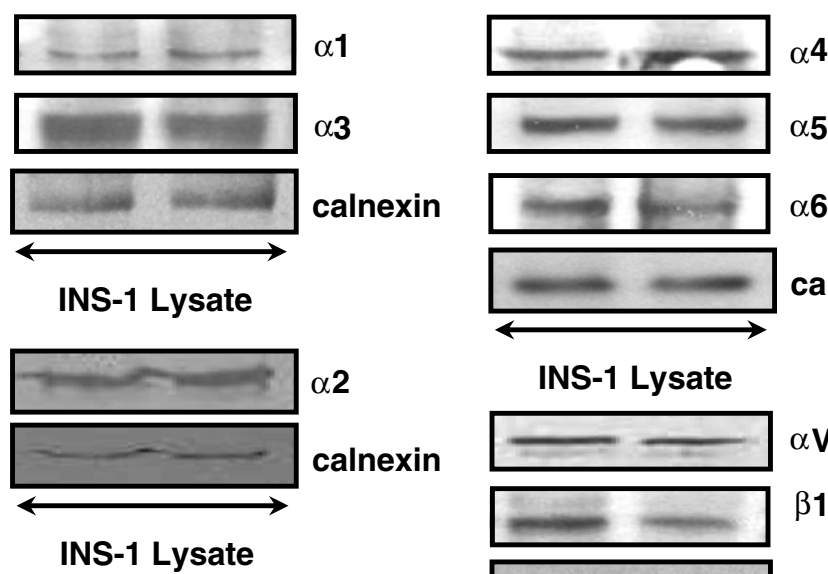

INS-1 Lysate

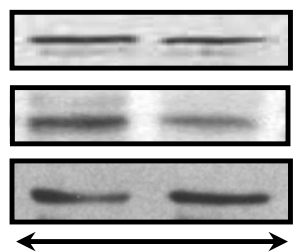

INS-1 Lysate

$\alpha \mathrm{V}$

$\beta 1$

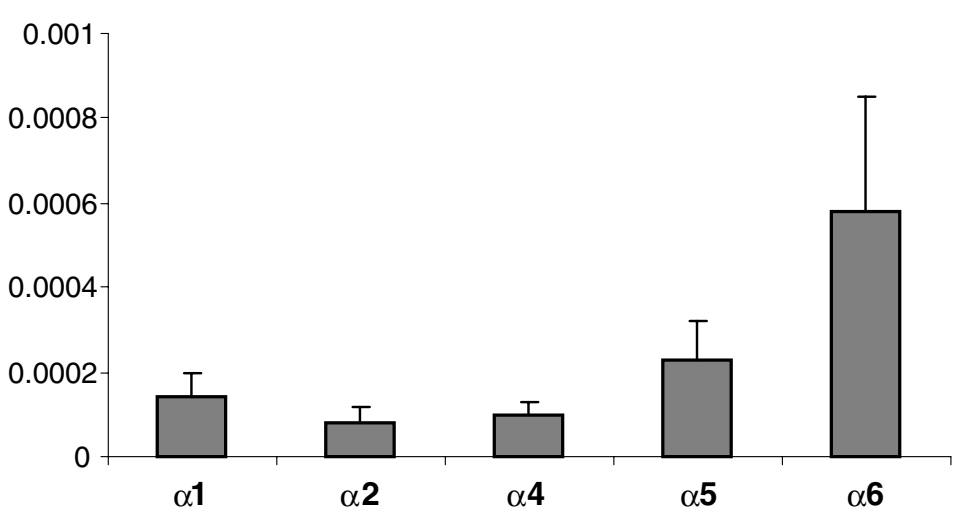

D

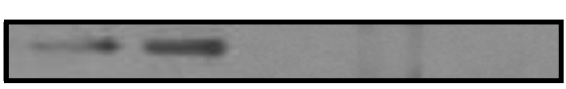

$\alpha 3$
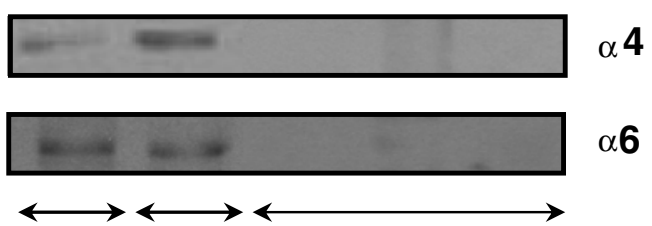

$\alpha 6$

INS-1 IP for $\beta 1$ Negative Controls

$\begin{array}{llll}\text { Lysate Integrin } & \text { (A) (B) } & \text { (C) }\end{array}$

calnexin

integrins $\alpha 3, \alpha 4$ and $\alpha 6$ with the $\beta 1$ integrin ( $n=4-6$ experiments/ group). Negative controls were performed by (a) addition of IgG (no $\beta 1$ antibody), (b) antibody and beads (no extract) (c) beads (no $\beta 1$ antibody or extract) 


\section{A fibronectin}

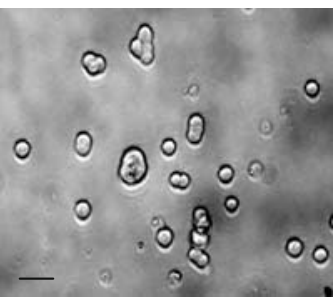

laminin

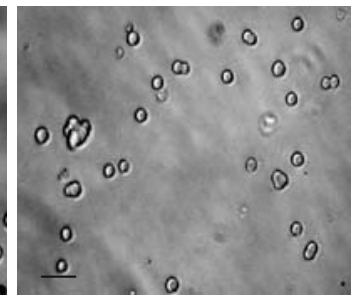

collagen I

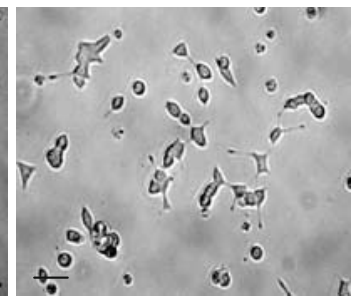

collagen IV

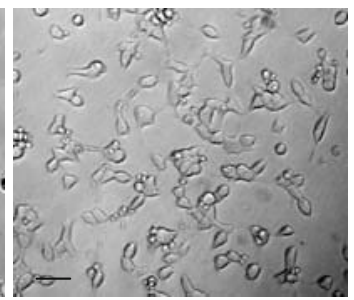

control

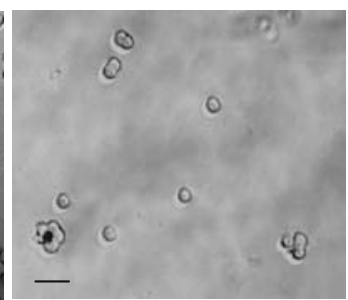

B

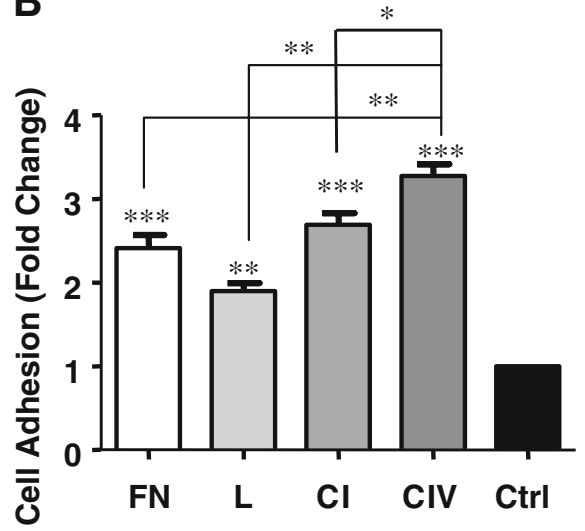

Fig. 2 Collagens I and IV enhance INS-1 cell adhesion and spreading. a Phase contrast micrographs of INS-1 cells cultured on fibronectin $(F N)$, laminin $(L)$, collagen I $(C I)$ and collagen IV $(C I V)$, or BSA

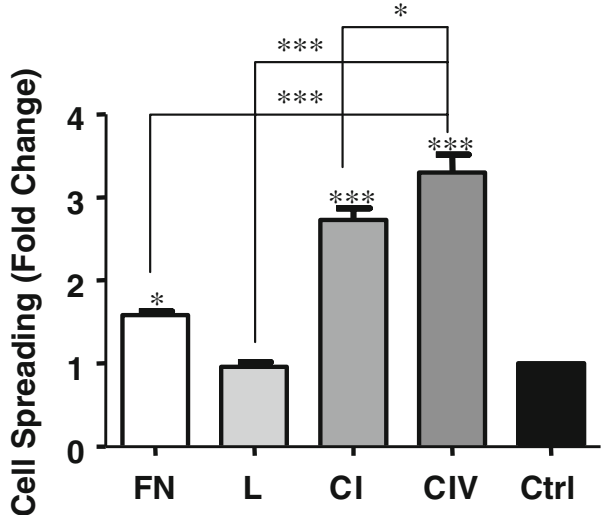

coated control $(\mathrm{Ctrl})$ for $24 \mathrm{~h}$ Scale bar: $40 \mu \mathrm{m}$. b Fold change of cell adhesion and spreading after $3 \mathrm{~h}$ of culture, ${ }^{*} p<0.05,{ }^{* *} p<0.01, * * * p$ $<0.001$ vs. control or other groups ( $n=6$ experiments/group)

to each well $3 \mathrm{~h}$ prior to collection. Cells were fixed in $4 \%$ paraformaldehyde, embedded in $2 \%$ agarose gel and processed into tissue blocks (Wang et al. 2005). Five micrometer sections from experimental groups were incubated with appropriately diluted primary antibodies listed in Table 1 . The secondary antibodies conjugated with fluorescein isothiocyanate (FITC) or tetramethyl rhodamine isothiocyanate (TRITC) were obtained from Jackson Immunoresearch Laboratories (West Grove, PA, USA). Nuclei were counterstained with DAPI. The percentage of immunoreactive cells was obtained by counting at least 500 cells per section per experimental group, with a minimum of six repeat experiments per group.

\section{Immunoprecipitation}

INS-1 lysates were precleared by incubation with $40 \mu \mathrm{l}$ of $50 \mathrm{mg} / \mathrm{ml} \mathrm{BSA}$ in lysis buffer and $5 \mu \mathrm{g}$ of $\beta 1$ integrin antibody (Chemicon). Lysates were incubated with $40 \mu$ of Protein-G beads (Santa Cruz Biotechnologies). Immune complexes were pelleted washed with lysis buffer (NonidetP40, phenylmethylsulfonyl fluoride, sodium orthovanadate [Sigma] and complete protease inhibitor cocktail tablet [Roche, Montreal, QC, Canada]) (Davis et al. 1998). After the final wash, each pellet was resuspended in $50 \mu \mathrm{l}$ of Laemmli sample buffer containing DTT and incubated at $100^{\circ} \mathrm{C}$ for $6 \mathrm{~min}$ (Davis et al. 1998). Samples were subdifferent matrix proteins for $24 \mathrm{~h}$. $10 \mu \mathrm{M}$ BrdU was added 
A

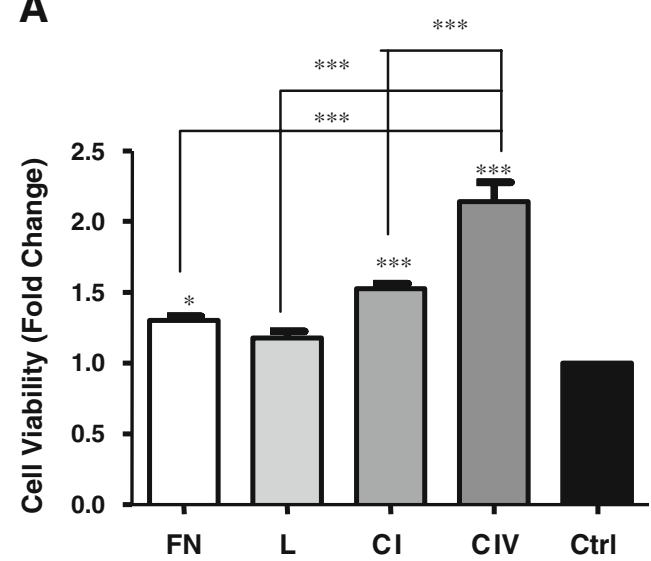

B

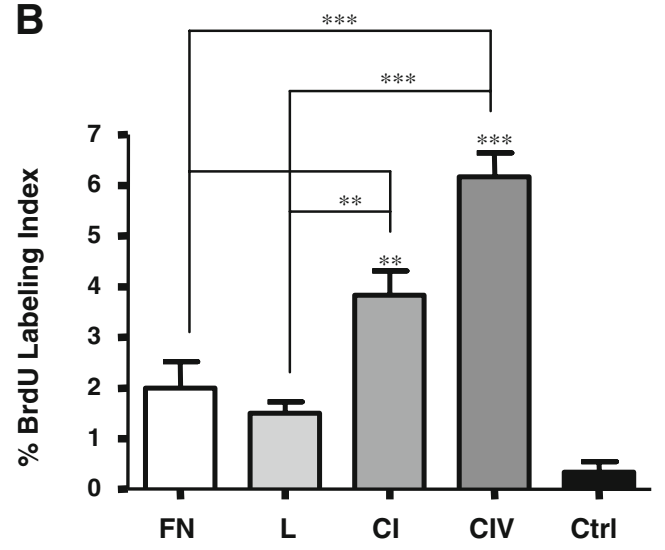

Fig. 3 Collagens I and IV increase INS-1 cell viability and proliferation. a MTT assay and $\mathbf{b}$ morphometric analysis of BrdU labeling index of INS-1 cells cultured on fibronectin $(F N)$, laminin $(L)$, collagen I $(C I)$ and collagen IV $(C I V)$, or BSA coated control $(C t r l)$ for $24 \mathrm{~h}\left(n=5-6\right.$ experiments/group). ${ }^{* *} p<0.01,{ }^{* * *} p<0.001$ vs. control and other groups

sequently analyzed through western blotting. Negative controls included the addition of IgG, no extract or beads alone.

\section{Protein extraction and Western blotting}

To determine the expression of $\alpha \beta 1$ integrins and FAK phosphorylation, proteins from INS-1 cells were extracted by sonicating in lysis buffer. (Wang et al. 2005), and centrifuged at $13,000 \mathrm{rpm}(12,879 \mathrm{x} \mathrm{g})$ for $20 \mathrm{~min}$ at $4^{\circ} \mathrm{C}$. Protein concentrations were measured using the Bradford assay (Bio-Rad Laboratories, Mississauga, ON, Canada) with bovine serum albumin (fraction V) as the standard. Equal amounts $(50 \mu \mathrm{g})$ of lysate from each experimental group was separated by either $7.5 \%$ or $10 \%$ sodium dodecyl sulfate-polyacrylamide gel electrophoresis (SDS-PAGE) and transferred to a nitrocellulose membrane (Bio-Rad Laboratories). Membranes were washed in Tris buffer-saline (TBS) containing $0.1 \%$ Tween -20 and blocked with $5 \%$ nonfat dry milk. Immunoblotting was performed with appropriate dilutions of primary antibodies as listed in Table 1. Appro- priate horse-radish peroxidase (HRP)-conjugated secondary antibodies were subsequently applied. Proteins were detected using ECL ${ }^{\text {TM}}$-Plus Western blot detection reagents (Perkin Elmer, Wellesley, MA, USA) and exposed to BioMax MR Film (Kodak, Rochester, NY, USA). Densitometric quantification of phosphorylated and total FAK protein levels was performed and normalized to total FAK (Wang et al. 2005).

RNA isolation and qRT-PCR

To determine the expression levels of $\beta 1$ and associated $\alpha$ subunits, Pdx-1 and insulin mRNA, total RNA was extracted from cells cultured in serum-containing medium or cells cultured on different matrix proteins for $24 \mathrm{~h}$ in serum-free medium, using the RNAqueous-4PCR kit (Ambion, Austin, TX, USA) (Wang et al. 2005). Synthesis of cDNA was performed with Superscript reverse transcriptase (Invitrogen). Primers used are listed in Table 2. Realtime RT-PCR analyses were performed using $0.1 \mu \mathrm{g}$ cDNA and the iQ SYBR Green Supermix kit in Chromo4 Real time PCR (Bio-Rad). Data were normalized to the $18 \mathrm{~S}$ RNA subunit, with at least six repeats per experimental group (Wang et al. 2005). Relative gene expression of Pdx1, insulin I and insulin II was calculated using the arithmetic formula " ${ }^{-\Delta \Delta C}$ " and normalized to control data (Livak and Schmittgen 2001).

\section{Glucose-stimulated insulin secretion assay}

INS-1 cells cultured on different matrix proteins for $24 \mathrm{~h}$ equilibrated in prewarmed oxygenated Krebs-Ringer bicarbonate HEPES buffer containing no glucose and $0.5 \%$ BSA, followed by $1 \mathrm{~h}$ in Krebs-Ringer bicarbonate HEPES buffer containing 2.2 or $22 \mathrm{mmol} / \mathrm{l}$ glucose. Insulin secretion and content was determined using a high range rat insulin ELISA kit (Alpco, Salem, New Hampshire, USA). Data are expressed as $\mathrm{ng} / \mathrm{ml}$ or as $\mathrm{ng} / \mathrm{mg}$ protein (Moibi et al. 2007).

Blockade $\alpha 3 \beta 1$ integrin using immunoneutralizing antibody

INS- 1 cells were incubated with both mouse anti-rat $\alpha 3$ (CD49c, $10 \mu \mathrm{g} / \mathrm{ml}$, Santa Cruz Biotechnologies) and hamster anti-rat $\beta 1(\mathrm{CD} 29,5 \mu \mathrm{g} / \mathrm{ml}, \mathrm{BD}$ Biosciences $)$ integrin antibodies, or mouse IgG isotype-matched negative control $(10 \mu \mathrm{g} / \mathrm{ml})$ and hamster IgM isotype-matched negative control $(5 \mu \mathrm{g} / \mathrm{ml}$,), or left untreated in serum-free medium [RPMI-1640 with $1 \%$ bovine serum albumin (BSA)] for $1 \mathrm{~h}$ prior to being plated on $5 \mu \mathrm{g} / \mathrm{ml}$ of rat collagen I or collagen IV coated culture plates and cultured for $24 \mathrm{~h}$. At the end of the culture period, cells were used for functional or survival assays. All culture experiments 
Fig. 4 Collagens I and IV increase focal adhesion contact expression and FAK phosphorylation in INS-1 cells. a Immunostaining for vinculin (green) and F-actin (red) of INS-1 cells cultured on fibronectin, laminin, collagen I, collagen IV and control for $24 \mathrm{~h}$. Nuclei are counterstained with DAPI. Arrows indicate focal contact assembly. Scale bar: $10 \mu \mathrm{m}$. b Western blot analysis of phosphorylated (P) and total (T) FAK expression following $24 \mathrm{~h}$ of cell culture on fibronectin (FN), laminin $(L)$, collagen $\mathrm{I}(C I)$ and collagen IV $(\mathrm{CIV})$, or BSA coated control (Ctrl) $(n=3$ experiments/group). ${ }^{*} p<0.05$, $* * p<0.01$ vs. control
A
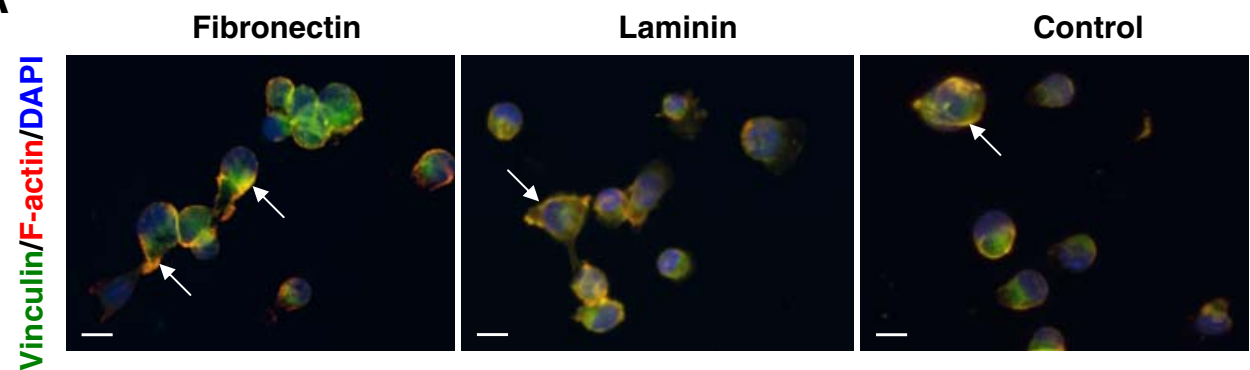

Collagen I
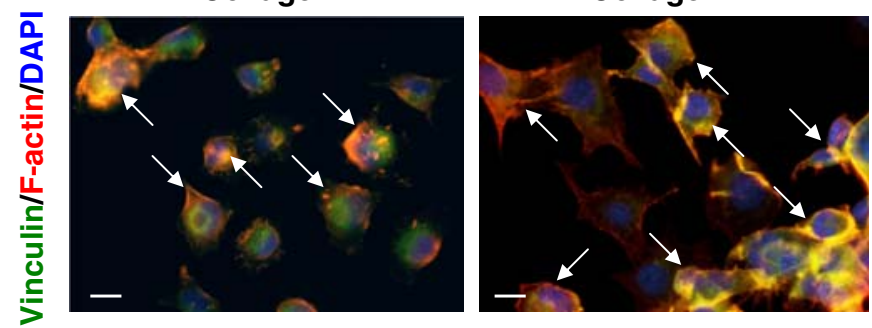

B
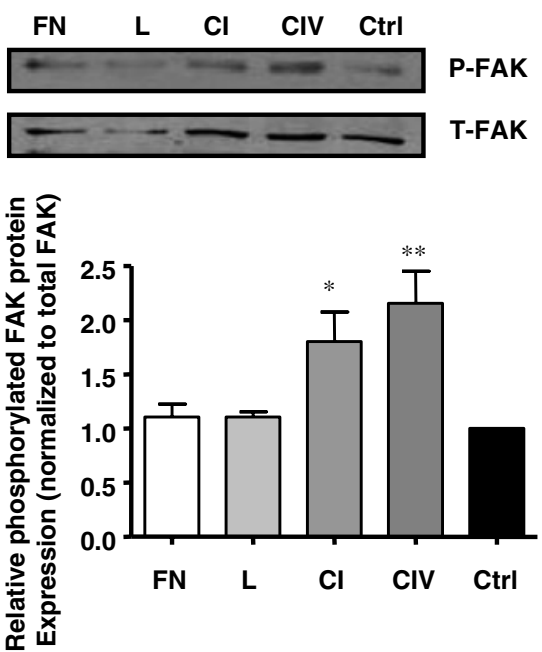

were conducted in triplicate with three to six repeat experiments per group.

\section{Statistical analysis}

Data are expressed as means \pm SEM. Statistical significance was determined using one-way ANOVA followed by the Least Significant Difference (LSD) or Bonferroni comparison test. Differences were considered to be statistically significant when $p<0.05$.

\section{Results}

Expression of $\alpha \beta 1$ integrins in INS-1 cells

To identify the most highly expressed $\alpha \beta 1$ integrins in the INS-1 cell line, several possible $\alpha$ subunits were screened.
Immunofluoresence microscopy demonstrated that integrin $\beta 1$ and its associated subunits $\alpha 1, \alpha 2, \alpha 3, \alpha 4, \alpha 5, \alpha 6$ and $\alpha \mathrm{V}$ are all expressed (Fig. 1a). Gene expression analysis through qRT-PCR revealed that integrins $\alpha 3$ and $\beta 1$ are the most highly expressed (Fig. 1b). Western blotting analysis confirmed the expression of integrin subunits $\alpha 1-6, \alpha \mathrm{V}$ and $\beta 1$ (Fig. 1c), while co-immunoprecipitation studies revealed the association of integrins $\alpha 3, \alpha 4$ and $\alpha 6$ with $\beta 1$ (Fig. 1d).

Collagen I and IV matrix proteins enhance INS-1 cell adhesion and spreading

The most common ligands for integrin $\alpha 3 \beta 1$ are fibronectin, laminin, collagen I and collagen IV (Coppolino et al. 1995; Delwel et al. 1994). The effect of these four matrices vs. control conditions on adhesion and spreading of these cells was tested. INS-1 cells demonstrated marked increases 
in adhesion on all matrices tested in comparison to control $(p<0.01-0.001$, Fig. 2a and b). Collagens I and IV provided maximum cell spreading in comparison to other matrix proteins and control groups $(p<0.001$, Fig. 2a and c); culturing on fibronectin caused a marginal increase $(p<0.05$ vs. control), while exposure to laminin failed to demonstrate any increases in cell spreading (Fig. 2a and c).

Collagens I and IV increase INS-1 cell survival and proliferation

To assess changes in cell viability upon contact with fibronectin, laminin, collagen I, collagen IV or control, MTT assays were performed. Exposure to collagens I or IV for $24 \mathrm{~h}$ resulted in significant increases in viability, with collagen IV showing the greatest changes (Fig. 3a). Cell viability was also slightly increased in cells cultured on fibronectin $(p<0.05)$, while contact with laminin demonstrated no change when compared to control (Fig. 3a).

To corroborate the noted alterations in cell viability, cell proliferation was examined using BrdU labeling. An increase in the number of $\mathrm{BrdU}^{+}$cells was noted on both collagens I (3.5-fold) and IV (6-fold) in comparison to control (Fig. 3b), while no changes were noted in the number of BrdU-labelled cells on fibronectin and laminin (Fig. 3b).

Collagens I and IV stimulate the formation of focal adhesion contacts and increase FAK phosphorylation

Focal adhesions are sites of contact between extracellular matrices and intracellular actin stress fibers which enable intracellular signal propogation to enhance cell survival and function (Berman et al. 2003). Therefore actin cytoskeleton and focal contacts were examined in INS-1 cells cultured on the different matrix proteins. INS-1 cells cultured on collagens I and IV for $24 \mathrm{~h}$, demonstrated greater focal adhesion contact formation (Fig. 4a), along with increased FAK phosphorylation (Fig. 4b) when compared to fibronectin, laminin and control.

Collagens I and IV increase Pdx-1 and insulin expression in INS-1 cells

Pdx-1 is an essential transcription factor expressed in beta cells, responsible for maintaining its phenotype and

A

A
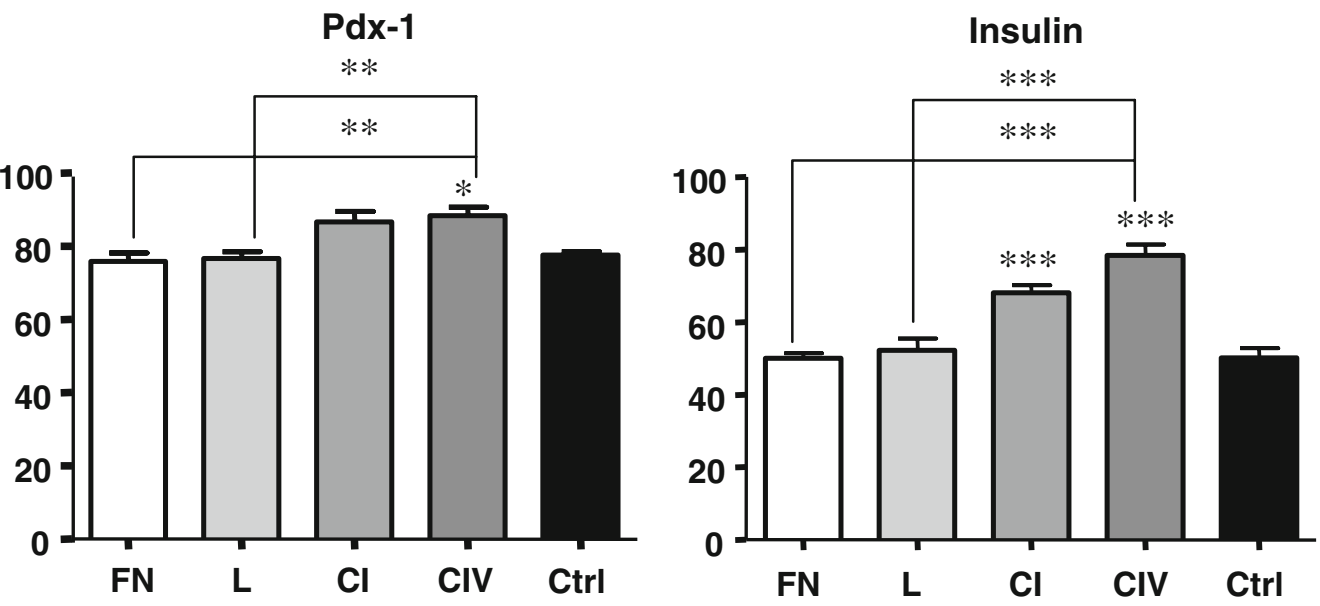

B

Pdx-1

Insulin I

Insulin II
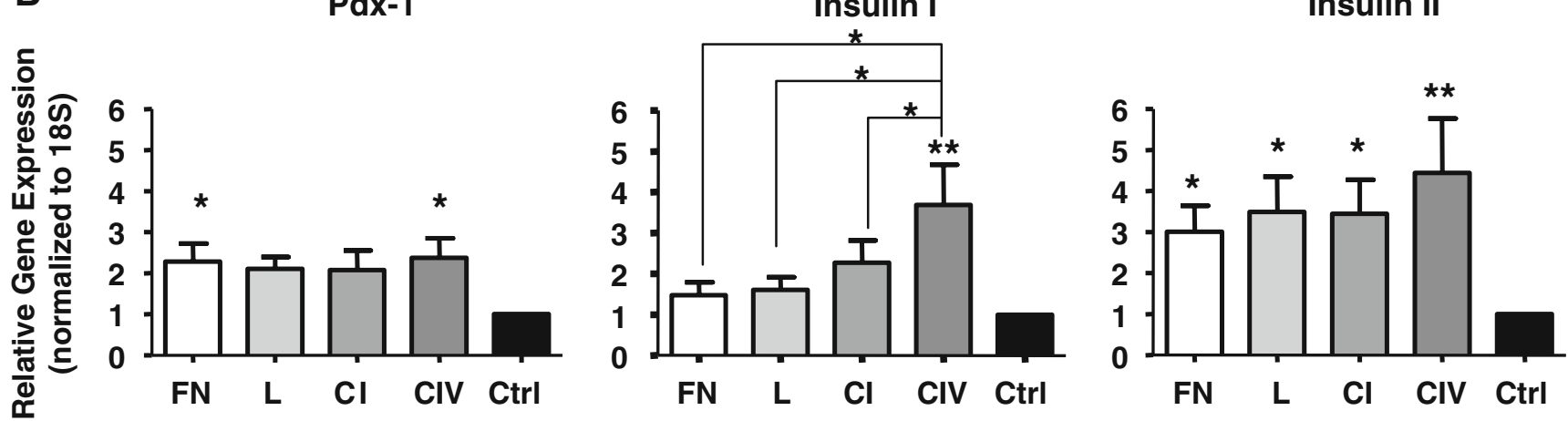

Fig. 5 Collagens I and IV enhance Pdx-1 and insulin gene and protein expression in INS-1 cells. a Morphometric analysis of Pdx-1 and insulin expression following a $24 \mathrm{~h}$ culture $(n=5-6$ experiments/ group). b qRT-PCR analysis of Pdx-1, Insulin I and Insulin II following $24 \mathrm{~h}$ of culture ( $n=6$ experiments/group). ${ }^{*} p<0.05,{ }^{*} p<$ $0.01, * * * p<0.001$ vs. control and other groups 
ensuring adequate insulin expression (Piper et al. 2004). INS- 1 cells cultured on collagen IV demonstrated increased Pdx-1 protein expression when compared to control $(p<$ $0.05)$, fibronectin and laminin $(p<0.01)$, with no significant differences to cells cultured on collagen I (Fig. 5a). qRTPCR analysis revealed an increase in Pdx-1 mRNA in cells
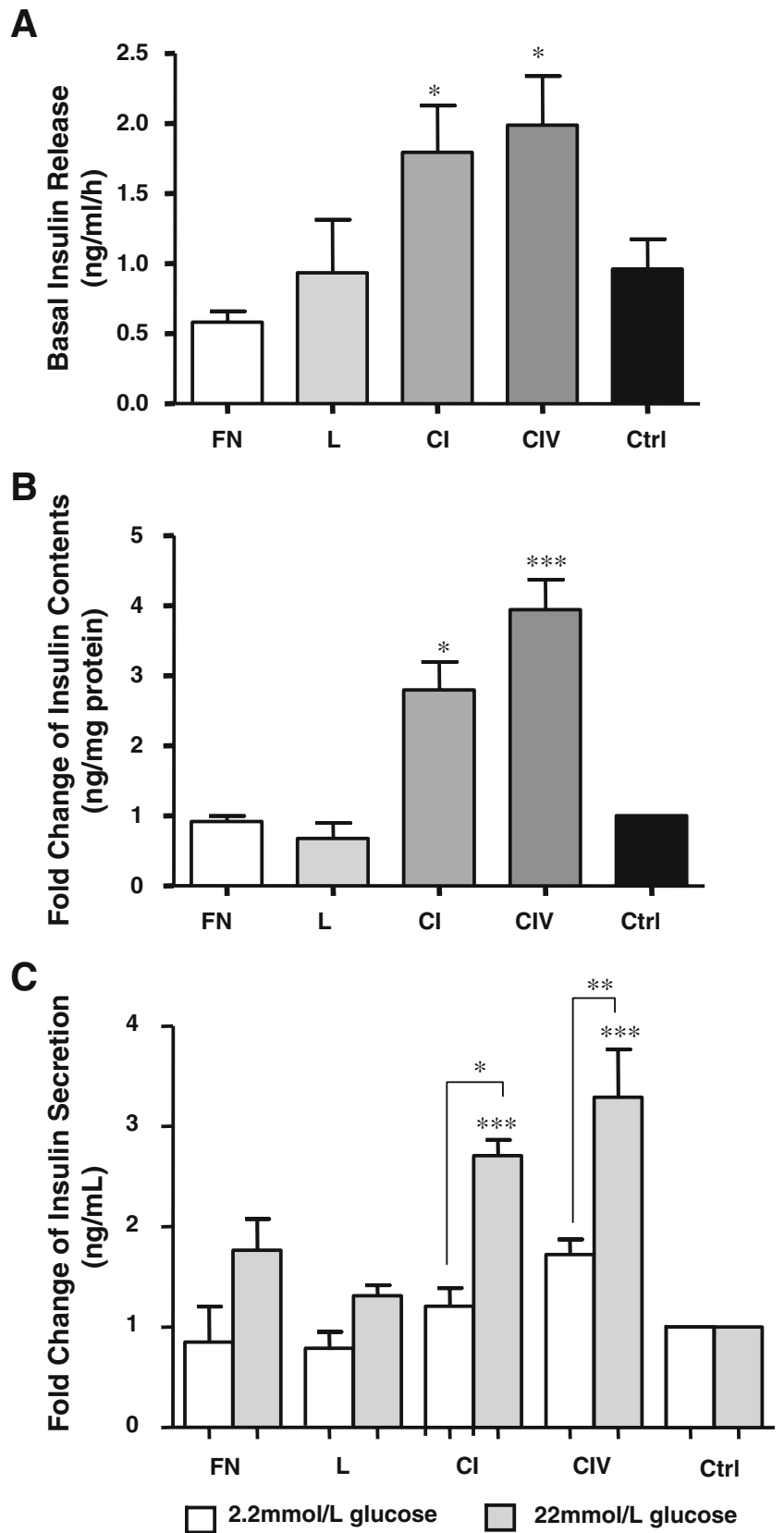

Fig. 6 Collagens I and IV increase basal insulin release, insulin content and enhance insulin secretion upon acute glucose challenge. a Basal insulin release ( $n=6$ experiments/group), b cellular insulin content and $\mathbf{c}$ glucose-stimulated insulin secretion from INS-1 cells cultured on fibronectin $(F N)$, laminin $(L)$, collagen $\mathrm{I}(C I)$ and collagen IV $(C I V)$, or BSA coated control $(C t r l)$ for $24 \mathrm{~h}(n=3$ experiments/ group). ${ }^{*} p<0.05, * * p<0.01,{ }^{* * *} p<0.001$ vs. control exposed to collagen IV when compared to control $(p<0.015$, Fig. 5b). The number of insulin ${ }^{+}$cells in both collagen I and IV groups were also observed to be significantly higher than that of controls $(p<0.001$, Fig. 5a). However, cells cultured on collagen IV matrix showed the greatest increase in insulin expression at both the mRNA $(p<0.016)$ and protein $(p<0.001)$ level when compared to controls or other matrices tested (Fig. 5).

Collagens I and IV enhance insulin secretion in INS-1 cells

INS-1 cells were cultured on different matrix proteins for $24 \mathrm{~h}$ and assessed for basal insulin release. Cells exposed to collagen I or IV showed enhanced basal insulin release when compared to controls $(p<0.05$, Fig. 6a), and displayed a 2 and 2.3 fold increase, respectively, in basal insulin levels. These increases in basal insulin release were associated with an increase in cellular insulin content (Fig. 6b). A glucose-stimulated insulin secretion test revealed no significant change in insulin secretion at a low dose of glucose $(2.2 \mathrm{mmol} / \mathrm{L}$, Fig. $6 \mathrm{c})$. However, cells challenged with high glucose $(22 \mathrm{mmol} / \mathrm{L})$ demonstrated a significant increase in insulin secretion on both collagens I (1.5-fold, $p<$ $0.05)$ and IV (1.6-fold, $p<0.01)$ compared to the $2.2 \mathrm{mmol} / \mathrm{L}$ glucose dose (Fig. 6c). Upon high glucose challenge, INS-1 cells demonstrated a 2.7 and 3.3 fold increase in insulin release on collagens I and IV, respectively, when compared to control $(p<0.001$, Fig. $6 c)$. Cells cultured on fibronectin and laminin demonstrated a lower, non-significant insulin secretory response to high glucose challenge (Fig. 6c).

Collagens I and IV increase $\alpha 3$ and $\beta 1$ integrin gene expression

Alterations in the gene expression of integrin receptors following $24 \mathrm{~h}$ exposure to fibronectin, laminin, collagens I and IV and control were examined. An increase in $\beta 1$ and $\alpha 3$ integrin gene expression was observed on both collagen I $(p<0.05)$ and collagen IV $(p<0.01)$ when compared to controls (Fig. 7), whereas no changes were observed in $\alpha 5$ and $\alpha 6$ integrin expression.

Blocking $\alpha 3 \beta 1$ integrin reduces INS- 1 cell adhesion, spreading and survival on collagens I and IV

Given that $24 \mathrm{~h}$ cell culture on collagen I and IV increases $\alpha 3 \beta 1$ integrin expression, the results of blocking this integrin were examined. Functional blockade of the $\alpha 3 \beta 1$ integrin significantly reduced INS- 1 cell adhesion and spreading on both collagen I and IV $(p<0.001)$ when compared to controls (untreated and $\operatorname{IgM} / \operatorname{IgG}$ ) (Fig. 8a,b). A decrease in cell viability was also observed by MTT assay when compared to controls (untreated and IgM/IgG) $(p<0.001$, Fig. 8b). More- 
Fig. 7 Collagens I and IV increase $\alpha 3$ and $\beta 1$ integrin gene expression in INS-1 cells. qRTPCR analysis of $\beta 1, \alpha 3, \alpha 5$, and $\alpha 6$ gene expression following $24 \mathrm{~h}$ of culture $(n=3-4$ experiments/group). ${ }^{*} p<0.05$, $* * p<0.01$ vs. control $\beta 1$ integrin

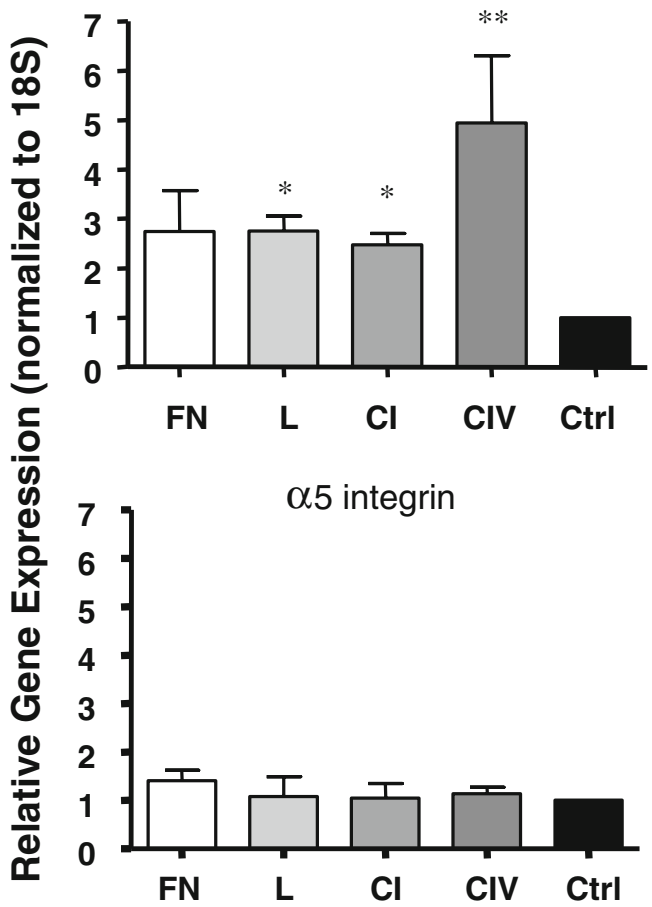

$\alpha 3$ integrin
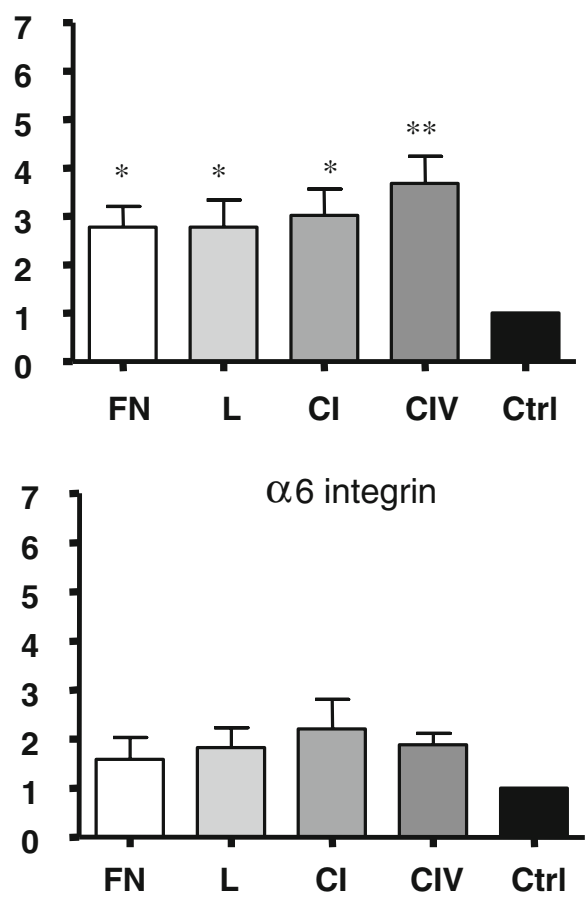

over, a significant decrease in $\mathrm{Pdx}-1$ and insulin protein expression was observed on collagens I $(p<0.01-0.001)$ and IV $(p<0.001)$, upon $\alpha 3 \beta 1$ blockade, when compared to controls (untreated and $\mathrm{IgM} / \mathrm{IgG}$ ).

\section{Discussion}

The present study characterizes the $\alpha \beta 1$ integrin expression pattern in INS-1 cells and demonstrates that integrindependent attachment to collagens I and IV are important for survival and function of the beta cells. INS-1 cells cultured on collagens I and IV showed remarkable increases in cell adhesion and spreading, paralleled by increases in INS-1 cell viability and proliferation. Moreover, an increase in focal adhesion contact assembly and FAK phosphorylation were observed in INS-1 cells cultured on collagen I or IV, when compared to other matrices tested and control. Integrin-dependent attachment to collagen I and IV also enhanced the expression of Pdx-1 and insulin mRNA and protein, and resulted in increased basal insulin release and insulin content in the cells, as well as augmented glucose-stimulated insulin secretion. Taken together, these findings indicate that specific interactions between integrin and collagen matrices are essential for the survival and function of INS-1 beta cells.

The important role of the $\beta 1$ subfamily of integrins in regulating beta cell survival and function has been well established. We have previously characterized the spatial and temporal expression patterns of the $\beta 1$ integrin and its associated subunits $\alpha 3, \alpha 5$ and $\alpha 6$ in the pre- and post-natal rat pancreas and during human fetal pancreatic development (Wang et al. 2005; Yashpal et al. 2005). In the present study, using immunohistochemical, western blotting and qRT-PCR approaches, we identified seven $\alpha$ subunits associated with the $\beta 1$ integrin in INS-1 cells, and determined that $\alpha 3 \beta 1$ is the most highly expressed. Pleiotrophic binding of the $\alpha 3 \beta 1$ integrin to various matrix proteins suggests that its associations with the ECM would highly influence beta cell activities: fibronectin, laminin, and collagens I and IV have been previously described as ligands of the integrin $\alpha 3 \beta 1$ (Coppolino et al. 1995; Delwel et al. 1994). Our data demonstrate that INS-1 cells preferentially adhere to and spread on collagens I and IV in comparison to fibronectin and laminin. Although both collagen matrices augment cell viability and proliferation, exposure to collagen IV maximally increased the number of viable and BrdUlabelled cells.

Molecular scaffolds which link the intracellular actin cytoskeleton with signaling proteins have been shown to promote adhesion, protect against apoptosis and enhance cell function (Berman et al. 2003; Boudreau and Jones 1999). In INS-1 cells, matrices collagen I and IV improved focal contact assembly and increased FAK phosphorylation, indicating that these collagen matrices are essential for the survival of beta cells. 
A Anti- $\beta 1 /$ Anti- $\alpha 3$

$\lg M / \lg G$

Ctrl
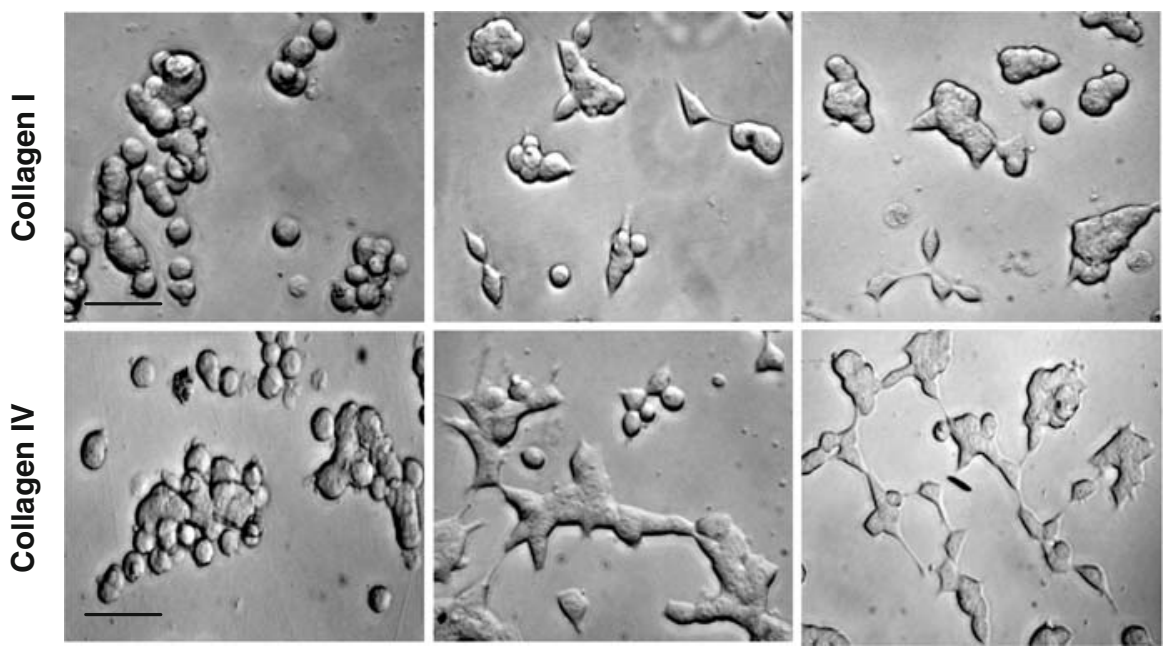

B
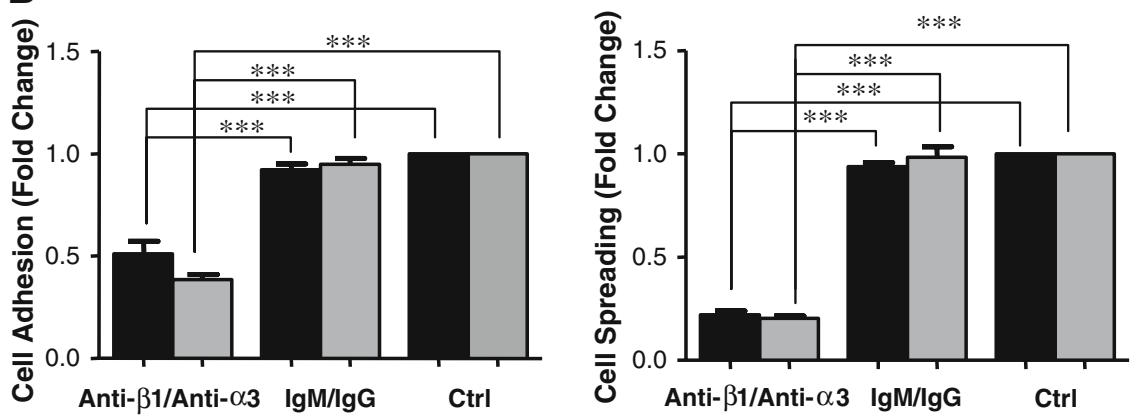

Collagen I

Collagen IV
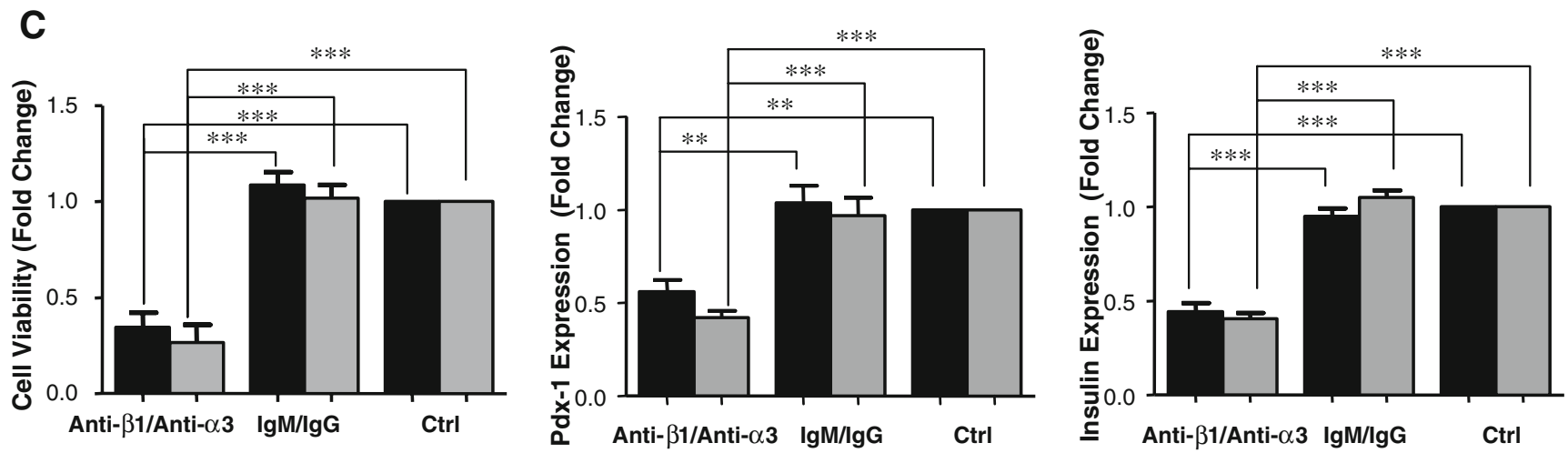

Fig. $8 \alpha 3 \beta 1$ integrin blockade reduced INS-1 cell survival and function on collagens I and IV. a Phase contrast micrographs of INS-1 cells treated with anti- $\beta 1 /$ anti- $\alpha 3, \operatorname{IgM} / \operatorname{IgG}$, or untreated (ctrl) on collagens I or IV for $24 \mathrm{~h}$ Scale bar: $40 \mu \mathrm{m}$ b Measurement of INS-1 cell adhesion and spreading after $3 \mathrm{~h}$ of culture. c Quantitative analysis

Functional analyses of these integrin-ECM interactions demonstrated increased insulin expression, basal insulin release and secretion in response to high doses of glucose when INS-1 cells were exposed to collagens I and IV in comparison to fibronectin or laminin. Although both collagen matrices enhanced insulin release at low and high doses of glucose, the insulin secretory response was much of cell viability assayed by MTT, Pdx-1 and insulin expression following $24 \mathrm{~h}$ of culture on collagens I and IV with either anti- $\beta 1$ / anti- $\alpha 3$ or $\operatorname{IgM} / \operatorname{IgG}$ or untreated (ctrl) ( $n=3-4$ experiments/group). ${ }^{* *} p<0.01,{ }^{* * *} p<0.001$ vs. IgM/IgG or untreated controls

higher in cells cultured on collagen IV. In support of our findings, Kaido et al. reported that collagen IV greatly stimulates insulin release from human fetal islet cells in comparison to collagen I, fibronectin and laminin (Kaido et al. 2004). The findings of this study, along with our results demonstrate that attachment of beta cells to collagen matrices promote beta cell function. 
The findings of the present study demonstrate that INS-1 cell survival and function and $\alpha 3 \beta 1$ gene expression are increased on collagen I and IV, indicating that cell culture on collagen matrices stimulates both inside-out and outsidein signaling. Perturbing the $\alpha 3 \beta 1$ integrin decreased INS- 1 cell adhesion, spreading and viability on both collagen I and IV, and reduced Pdx-1 and insulin expression, revealing that $\alpha 3 \beta 1$ integrin interactions with collagen matrices are critical for beta cell survival.

The positive effects of culturing islets in either two or three-dimensional collagen I matrices have been previously documented. Montesano et al. (1983) developed a three-dimensional culture module where dispersed human islet cells were seeded on collagen I matrices and subsequently overlaid with an additional layer of collagen I. Embedding these islet cells allowed for their re-aggregation into organoids that resembled native islets (Montesano et al. 1983). Similarly, culturing canine, rat and human fetal islets on collagen I increased cell adhesion (Wang et al. 1999; Wang et al. 2005; Yashpal et al., 2005), stimulated basal insulin secretory responses from canine islets and reduced cell death (Wang et al. 1999). These findings are congruent with the results in the present study, which reinforce the concept that there are beneficial effects of collagen I on beta cell survival and function.

The majority of studies have highlighted the importance of traditional matrix proteins found in the islet, including fibronectin, laminin and collagen I. All three of these matrices have been shown to aid in the attachment of islet cells and augment insulin release following isolation (Hammar et al. 2004; Kaido et al. 2006; Wang et al. 1999). Although a major basement membrane constituent, collagen IV is a less well-studied matrix protein in islet cell biology. In situ, collagen IV is found in the basement membrane of intra-islet blood vessels (Kaido et al. 2004; Van Deijnen et al. 1994), and beta cells are closely associated with these structures (Lammert et al. 2003). The importance of collagen IV has been demonstrated by Kaido et al. (2004), who reported increased adhesion and migration of human fetal beta cells on this matrix protein (Kaido et al. 2004). Moreover, our previous studies have revealed the co-localization of collagen IV with the $\alpha 3$ integrin in human fetal pancreatic islets, suggesting that interactions between $\alpha \beta 1$ integrins and collagen IV have developmental and functional implications in vivo (Wang et al. 2005). Taken together with the findings in the present study, interactions between collagen IV and $\alpha \beta 1$ integrins are essential for the survival and function of beta cells, and should be further explored in islet cell biology.

In summary, in the present study we have characterized the $\alpha \beta 1$ integrin expression in the INS-1 pancreatic beta cell line and demonstrated how integrin-dependent adhesion to various ECM constituents, including fibronectin, laminin, collagen I and collagen IV, regulate beta cell survival and function. Our analyses provide insight into integrin-ECM associations that augment beta cell function in vitro. The identification and manipulation of such critical factors will be important in deriving optimal islet-based therapies for the treatment of diabetes.

Acknowledgements The authors are grateful to Dr. Cynthia G. Goodyer (Research Institute of Montreal Children Hospital, McGill) for her critical comments on the manuscript. This work was supported by grants from the Natural Sciences \& Engineering Research Council of Canada. Dr. Wang is supported by a New Investigator Award from Canadian Institutes of Health Research.

Open Access This article is distributed under the terms of the Creative Commons Attribution Noncommercial License which permits any noncommercial use, distribution, and reproduction in any medium, provided the original author(s) and source are credited.

\section{References}

Asfari M, Janjic D, Meda P, Li G, Halban PA, Wollheim CB (1992) Establishment of 2-mercaptoethanol-dependent differentiated insulin-secreting cell lines. Endocrinology 130:167-178 doi:10.1210/en.130.1.167

Berman AE, Kozlova NI, Morozevich GE (2003) Integrins: structure and signaling. Biochemistry 68:1284-1299

Bosco D, Meda P, Halban PA, Rouiller DG (2000) Importance of cellmatrix interactions in rat islet $\beta$ cell secretion in vitro: role of $\alpha 6 \beta 1$ integrin. Diabetes 49:233-243 doi:10.2337/diabetes.49.2.233

Boudreau NJ, Jones PL (1999) Extracellular matrix and integrin signalling: the shape of things to come. Biochem J 339:481-488 doi:10.1042/0264-6021:3390481

Bouvard D, Brakebusch C, Gustafsson E, Aszodi A, Bengtsson T, Bern A, Fassler A (2001) Functional consequences of integrin gene mutations in mice. Circ Res 89:211-223 doi:10.1161/ hh1501.094874

Brakebusch C, Fassler R (2005) $\beta 1$ integrin function in vivo: adhesion, migration and more. Cancer Metastasis Rev 24:403411 doi:10.1007/s10555-005-5132-5

Cirulli V, Beattie GM, Klier G, Ellisman M, Ricordi C, Quaranta V, Frasier F, Ishii JK, Hayek A, Salomon DR (2000) Expression and function of $\alpha \mathrm{vb} 3$ and $\alpha \mathrm{vb} 5$ Integrins in the developing pancreas: roles in the adhesion and migration of putative endocrine progenitor cells. J Cell Biol 150(6):1445-1449 doi:10.1083/ jcb.150.6.1445

Coppolino M, Migliorini M, Argraves WS, Dedhar S (1995) Identification of a novel form of the $\alpha 3$ integrin subunit: covalent association with the transferrin receptor. Biochem J 306:129-134

Coppolino MG, Dedhar S (1999) Bi-directional signal transduction by integrin receptors. Int $\mathrm{J}$ Biochem Cell Biol 32:171-188 doi:10.1016/S1357-2725(99)00043-6

Danen EHJ, Sonnenberg A (2003) Integrins in regulation of tissue development and function. J Pathol 200:471-480 doi:10.1002/ path. 1416

Davis E, Broekelmann TJ, Ozawa Y, Mecham RP (1998) Identification of tropoelastin as a Ligand for the 65-kD FK506-binding protein, FKBP65, in the secretory pathway. J Cell Biol 140 (2):295-303 doi:10.1083/jcb.140.2.295

Delwel OG, de Melker AA, Hogervorst F, Jaspars LH, Fles DLA, Kuikman I, Lindblom A, Paulsson M, Timpl R, Sonnenberg A (1994) Distinct and overlapping ligand binding specificities of 
the $\alpha 3 \mathrm{~A} \beta 1$ and $\alpha 6 \mathrm{~A} \beta 1$ integrins: recognition of laminin isoforms. Mol Biol Cell 5:203-215

French-Constant CF, Colognato H (2004) Integrins: versatile integrators of extracellular signals. Trends Cell Biol 14(12):678-695 doi:10.1016/j.tcb.2004.10.005

Hammar E, Parnaud G, Bosco D, Perriraz N, Maedler K, Donath M, Rouiller G, Halban PA (2004) Extracellular matrix protects pancreatic $\beta$-cells against apoptosis: role of short- and long-term signaling pathways. Diabetes 53:2034-2041 doi:10.2337/ diabetes.53.8.2034

Janjic D, Wollheim C (1992) Effect of 2-mercaptoethanol on glutathione levels, cystine uptake and insulin secretion in insulin secreting cells. Eur J Biochem 210:297-304 doi:10.1111/j.14321033.1992.tb17421.x

Jensen P, Knop B, Chen FK, Hohmeier G, Mulder HE, Newgard CB (2001) Identification of genes involved in glucose-stimulated insulin secretion. Diabetes 50(1):S134 doi:10.2337/diabetes.50.2007.S134

Juliano RL, Reddig P, Alahari S, Edin M, Howe A, Aplin A (2004) Integrin regulation of cell signalling and motility. Biochem Soc Trans 32(3):443-446 doi:10.1042/BST0320443

Kaido T, Yebra M, Cirulli V, Montgomery AM (2004) Regulation of human beta-cell adhesion, motility, and insulin secretion by collagen IV and its receptor $\alpha 1 \beta 1$. J Biol Chem 279:5376253769 doi:10.1074/jbc.M411202200

Kaido T, Yebra M, Cirulli V, Rhodes C, Diaferia G, Montgomery AM (2006) Impact of defined matrix interations on insulin production by cultured human $\beta$-cells. Diabetes 55:2723-2729 doi:10.2337/ db06-0120

Kantengwa S, Beatens D, Sadoul K, Buck CA, Halban PA, Rouiller DG (1997) Identification and characterization of $\alpha 3 \beta 1$ on primary and transformed rat islet cells. Exp Cell Res 237:394 402 doi:10.1006/excr.1997.3803

Lammert E, Gu G, McLaughlin M, Brown D, Brekken R, Murtaugh LM, Gerber HP, Ferrara N, Melton DA (2003) Role of VEGF-A in vascularization of pancreatic islets. Curr Biol 13:1070-1074 doi:10.1016/S0960-9822(03)00378-6

Lee JW, Juliano R (2004) Mitogenic Signal Transduction by Integrinand Growth Factor receptor-mediated pathways. Mol Cells 17 (2): $188-202$

Li J, Goodyer CG, Fellows F, Wang R (2006) Stem cell factor/c-kit interactions regulate human islet-epithelial cluster proliferation and differentiation. Int $\mathrm{J}$ Biochem Cell Biol 38:961-972 doi:10.1016/j.biocel.2005.08.014

Livak KJ, Schmittgen TD (2001) Analysis of relative gene expression data using real-time quantitative PCR and the $2^{-\Delta \Delta C T}$ Method. Methods 25:402-408 doi:10.1006/meth.2001.1262
Moibi JA, Gupta D, Jetton TL, Peshavaria M, Desai R, Leahy J (2007) Peroxisome proliferator-activated receptor- $\gamma$ regulates expression of PDX-1 and NKX6.1 in INS-1 Cells. Diabetes 56:88-95 doi:10.2337/db06-0948

Montesano R, Mouron P, Amherdt M, Orci L (1983) Collagen matrix promotes pancreatic endocrine cell reorganization of monolayers into islet-like organoids. J Cell Biol 97:935-939 doi:10.1083/jcb.97.3.935

Pedersen KB, Zhang P, Doumen C, Charbonnet M, Lu D, Newgard CB, Haycock JW, Lange AJ, Scott DK (2007) The promoter for the gene encoding the catalytic subunit of rat glucose-6phosphatase contains two distinct glucose-responsive regions. Am J Physiol Endocrinol Metab 319(5868):1402-1405

Piper K, Brickwood S, Turnpenny LW, Cameron IT, Ball SG, Wilson DI, Hanley NA (2004) Beta cell differentiation during early human pancreas development. J Endocrinol 181:11-23 doi:10.1677/joe. 0.1810011

Thiery JP (2003) Cell adhesion in development: a complex signaling network. Curr Opin Genet Dev 13:365-371 doi:10.1016/S0959437X(03)00088-1

Van Deijnen JH, Van Suylichem PT, Wolters GH, Van Schilfgaarde R (1994) Distribution of collagens type I, type III and type V in the pancreas of rat, dog, pig and man. Cell Tissue Res 277:115-121 doi:10.1007/BF00303087

Wang R, Paraskevas S, Rosenberg L (1999) Characterization of integrin expression in islets isolated from hamster, canine, porcine, and Human pancreas. J Histochem Cytochem 47 (4):499-506

Wang R, Rosenberg L (1999) Maintenance of $\beta$-cell function and survival following islet isolation requires re-establishment of the islet-matrix relationship. J Endocrinol 163:181-190 doi:10.1677/ joe. 0.1630181

Wang R, Li J, Rosenberg L (2001) Factors mediating the transdifferentiation of islets of Langerhans to duct epithelial-like structures. J Endocrinol 171:309-318 doi:10.1677/joe.0.1710309

Wang R, Li J, Lyte K, Yashpal NK, Fellows F, Goodyer C (2005) Role of $\beta 1$ integrin and its associated $\alpha 3, \alpha 5$ and $\alpha 6$ subunits in the development of the human fetal pancreas. Diabetes 54:2080 2089 doi:10.2337/diabetes.54.7.2080

Yashpal NK, Li J, Wheeler MB, Wang R (2005) Expression of $\beta 1$ integrin receptors during rat pancreas development - sites and dynamics. Endocrinology 146(4):1798-1807 doi:10.1210/en.2004-1292

Yang S, Fransson U, Fagerhus L, Stenson-Holst L, Hohmeier HE, Renstrom E, Mulder H (2004) Enhanced cAMP protein kinase a signaling determines improved insulin secretion in a clonal insulin-producing $\beta$-Cell line (INS-1 832/13). Mol Endocrinol 18(9):2312-2320 doi:10.1210/me.2004-0148 